\title{
FTY720 (Fingolimod) attenuates basal and sphingosine-1-phosphate-evoked thyroid cancer cell invasion
}

\author{
Veronica Kalhori1,2, Melissa Magnusson1,2, Muhammad Yasir Asghar1, Ilari Pulli1 and \\ Kid Törnquist1,2
}

1Department of Biosciences, Åbo Akademi University, Turku, Finland

${ }^{2}$ The Minerva Foundation Institute for Medical Research, Biomedicum Helsinki, Helsinki, Finland
Correspondence should be addressed to K Törnquist

Email

ktornqvi@abo.fi

\begin{abstract}
The bioactive lipid sphingosine-1-phosphate (S1P) is a potent inducer of ML-1 thyroid cancer cell migration and invasion. It evokes migration and invasion by activating S1P

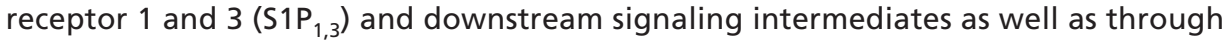
cross-communication with vascular endothelial growth factor receptor 2 (VEGFR2). However, very little is known about the role of S1P receptors in thyroid cancer.

Furthermore, the currently used treatments for thyroid cancer have proven to be rather unsuccessful. Thus, due to the insufficiency of the available treatments for thyroid cancer, novel and targeted therapies are needed. The S1P receptor functional antagonist FTY720, an immunosuppressive drug currently used for treatment of multiple sclerosis, has shown promising effects as an inhibitor of cancer cell proliferation and invasion. In this study, we investigated the effect of FTY720 on invasion and proliferation of several thyroid cancer cell lines. We present evidence that FTY720 attenuated basal as well as S1P-evoked invasion of these cell lines. Furthermore, FTY720 potently downregulated S1P, protein kinase $\mathrm{C} \alpha(\mathrm{PKC} \alpha), \mathrm{PKC} \beta \mathrm{I}$, and VEGFR2. It also attenuated S1P-evoked phosphorylation of ERK1/2. Our results also showed that FTY720 attenuated S1P-induced MMP2 intracellular expression, S1P-induced secretion of MMP2 and MMP9, and decreased basal MMP2 and MMP9 activity. Moreover, in FTY720-treated cells, proliferation was attenuated, p21 and p27 were upregulated, and the cells were arrested in the G1 phase of the cell cycle. FTY720 attenuated cancer cell proliferation in the chick embryo chorioallantoic membrane assay. Thus, we suggest that FTY720 could be beneficial in the treatment of thyroid cancer.
\end{abstract}

Key Words
thyroid
cancer
- sphingosine-1-phosphate
- invasion
- proliferation

Endocrine-Related Cancer (2016) 23, 457-468

\section{Introduction}

Sphingosine-1-phosphate (S1P) is a member of the sphingomyelin family of bioactive lipids regulating several central cellular processes. It is generated in cells from sphingosine by the action of sphingosine kinase 1 (SK1) and is transported out from the cells by the aid of several transport mechanisms. However, a role for S1P as an intracellular messenger has become evident during the past few years (Alvarez et al. 2007, Strub et al. 2010, Alshaker et al. 2013, Pyne \& Pyne 2013, Takabe \& Spiegel 2014).

Extracellular S1P elicits its effects through binding to one of its five highly specific G-protein-coupled receptors, termed $\mathrm{S}_{1} \mathrm{P}_{1-5}$, and by activating different G-proteins.

Published by Bioscientifica Ltd 
The final outcome of S1P treatment, however, is dependent on which receptor and G-protein it activates. As most cell types express receptors for S1P, this metabolite is unambiguously an important regulator of cell function during normal development and normal physiology. In addition, a substantial amount of evidence has implicated S1P in the progression of several types of cancers by enhancing many central events such as proliferation, angiogenesis, migration, and invasion (Alvarez et al. 2007, Strub et al. 2010, Alshaker et al. 2013, Pyne \& Pyne 2013, Takabe \& Spiegel 2014).

The importance of sphingolipids in thyroid cancer has not been studied in great detail. We have shown that S1P is without an effect on the proliferation and invasion of normal thyroid cells but induces a marked migration and invasion of ML-1 follicular thyroid cancer cells. This effect is mediated by $\mathrm{S}_{1} \mathrm{P}_{1 / 3}, \mathrm{G}_{\mathrm{i} / 0}$, PI3-kinase, protein kinase $\mathrm{C}$ (PKC), and ERK1/2 kinase (Balthasar et al. 2006, Bergelin et al. 2010). Furthermore, we have identified hypoxiainduced factor- $1 \alpha$ (HIF-1 $\alpha$ ) (Kalhori et al. 2013) and matrix metalloproteinases 2 and 9 (MMP2 and MMP9) (Kalhori \& Törnquist 2015) as mediators of the S1P-evoked migration and invasion of ML-1 cells. Moreover, SK1 enhances migration and invasion through an autocrine mechanism in these cells (Bergelin et al. 2009, 2010). Thus, in thyroid cancer cells, S1P-evoked signaling induces an aggressive and invasive phenotype. This is strengthened by observations that SK1 is overexpressed in thyroid cancer and correlates with a high degree of thyroid malignancy and poor prognosis (Guan et al. 2011).

In almost all forms of thyroid cancer, vascular endothelial growth factor receptor 2 (VEGFR2) and the secretion of VEGF are upregulated, enhancing the development of metastasis through an autocrine mechanism (Turner et al. 2003, Vieira et al. 2005, Kim et al. 2006). Our investigations have shown a complex cross talk between VEGFR2 and S1P receptors in ML-1 cells. This communication is of crucial importance for migration (Balthasar et al. 2008, Bergelin et al. 2010).

Fingolimod (FTY720) is an immunosuppressive drug approved by both the FDA and the EMA for treatment of multiple sclerosis (MS) and is presently the only available S1P receptor-modulating drug in clinical use. It

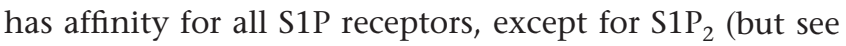
Sobel et al. 2015). Exogeneous FTY720 is taken up by cells, phosphorylated by SK2 (Paugh et al. 2003), and finally secreted into the extracellular space, where it binds to S1P receptors. This results in internalization and proteasomal degradation of the S1P receptors, events highlighting the inhibitory effects of FTY720 (Oo et al. 2007). In addition to its immunosuppressive effects in the treatment of MS, FTY720 has shown promising effects as an inhibitor of cancer cell migration and proliferation. This effect is due to, for example, inhibition of several key players in these cellular events, as well as by acting as an inhibitor of SK1 (Alshaker 2013, Kunkel et al. 2013, Pyne \& Pyne 2013, Selvam \& Ogretmen 2013).

The incidence of thyroid cancer has increased significantly worldwide. The prognosis for many forms of thyroid cancer is very good. However, there are certain aggressive forms with extremely poor and unfavorable prognosis. The available treatments for these forms have shown poor overall effects. Thus, to overcome the difficulties in treating thyroid cancer, new approaches are needed (Haugen \& Sherman 2013, Perri et al. 2014).

In this study, we have investigated the effect of FTY720 on the invasion and proliferation of thyroid cancer cells in vitro. Our results show that FTY720 efficiently inhibits both basal and S1P-evoked invasion by downregulating signaling intermediates of crucial importance for ML-1 cell migration. In addition, FTY720 attenuates the proliferation of thyroid cancer cells. Given the fact that FTY720 is already in clinical use for treatment of MS, we believe that it could be evaluated and considered for new medical indications. Thus, we suggest that FTY720 could be beneficial in the treatment of thyroid cancer.

\section{Materials}

\section{Reagents}

Dulbecco's modified Eagle's medium (DMEM), fatty acid-free bovine serum albumin (BSA), sodium pyruvate solution (1 $\mathrm{mM})$, propidium iodide (PI), Bafylomycin, MG132, ${ }^{3} \mathrm{H}$-thymidine, and FTY720 were purchased from Sigma-Aldrich. RMPI 1640 medium (without L-glutamine) was from Lonza (Basel, Switzerland). Fetal bovine serum (FBS), 2.5\% trypsin, L-glutamine, penicillin/ streptomycin, and F-12 (Ham's nutrient medium) were from GIBCO. S1P was from Biomol (Plymouth, PA, USA). The CellTiter 96 Aqueous One Solution Cell Proliferation

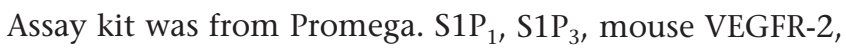
PKC $\alpha$ and PKC $\beta I$, and Hsc70 primary antibodies were from Santa Cruz Biotechnology. Horseradish peroxidase-conjugated goat anti-rabbit IgG was from Bio-Rad Laboratories. Antibodies against phospho- and total ERK1/2, HIF-1 $\alpha$ (WB), $\beta$-actin, SK1, MMP2, p21, p27, and anti-rat and anti-mouse IgG were from Cell Signalling Technology. MMP9 antibodies were from Abcam. Cell culture plastic ware and human collagen type IV were

Published by Bioscientifica Ltd 
from BD Biosciences. The Trans-well inserts for migration assays were from Coring. The nitrocellulose membrane was from PerkinElmer. The BCA (bicinchoninic acid) Protein Assay Reagent kit was from Pierce Biotechnology.

\section{Methods}

\section{Cell lines}

The follicular ML-1 thyroid cancer cells, provided by Dr Johann Schönberger (University of Regensburg, Germany), were cultured in DMEM supplemented with $2 \mathrm{mM}$ L-glutamine, $10 \% \mathrm{FBS}$ and $100 \mathrm{IU} / \mathrm{mL}$ penicillinstreptomycin (Schonberger et al. 2000). The FTC-133 follicular thyroid cancer cells were obtained from Banca Biologica e Cell Factory, National Institute for Cancer Research (Genova, Italy). The cells were grown in DMEM and Ham's F12 medium (1:1) supplemented with 10\% FBS and $2 \mathrm{mM}$ L-glutamine. The C643 anaplastic thyroid cancer cells, provided by Dr Nils-Erik Heldin (Karolinska Institute, Stockholm, Sweden), were cultured in DMEM supplemented with 10\% FBS, 1\% L-glutamine, and $1 \%$ penicillin-streptomycin. Normal human thyroid N-Thyr-Ori 3-1 cells (Culture Collections, Public Health England, Porton Down, Salisbury, UK) were grown in RPMI 1640 medium supplemented with $2 \mathrm{mM}$ glutamine, $10 \%$ FBS, and $1 \%$ penicillin-streptomycin. All cell lines were maintained in a humidified incubator at $37^{\circ} \mathrm{C}$ and $5 \%$ $\mathrm{CO}_{2}$. The cell lines not obtained from cell banks (the ML-1 and C643 cells) have been analyzed by DNA profiling by us (the ML-1 cells) and in the paper by Schweppe and coworkers (Schweppe et al. 2008). The C643 cells were obtained from the original source (Heldin), the same as Schweppe and coworkers (Schweppe et al. 2008). The FTC-133 cells were also analyzed by Schweppe and coworkers (Schweppe et al. 2008). All cell lines are authentic thyroid cancer cell lines. The cell passage never exceeded passage 28.

\section{Western blot}

Cells were treated as indicated, washed 3 times with ice-cold PBS, and lysed in cell lysis buffer $(10 \mathrm{mM}$ Tris (pH 7.7), $150 \mathrm{mM} \mathrm{NaCl}, 7 \mathrm{mM}$ EDTA, $0.5 \% \mathrm{NP}-40,0.2 \mathrm{mM}$ phenylmethylsulfonyl fluoride (PMSF), and $0.5 \% \mathrm{~g} / \mathrm{mL}$ leupeptin). Thereafter, the lysates were centrifuged at $15,000 \mathrm{~g}$ for $15 \mathrm{~min}$ at $4^{\circ} \mathrm{C}$, after which the supernatants were collected, protein concentration was determined using the BCA Protein Assay Kit, and Laemmli sample buffer was added to the samples. The samples were subjected to SDS/PAGE (8-12\% polyacrylamide); thereafter, proteins were transferred onto nitrocellulose membrane by Western blotting. Next, membranes were incubated with primary antibodies targeted against specific proteins overnight, followed by incubation with secondary antibodies for $1 \mathrm{~h}$ at room temperature. Finally, the proteins were detected by enhanced chemiluminescence, and densitometric analysis was performed using ImageJ software (http://rsb.info. nih.gov/ij/). Results were normalized against $\beta$-actin expression in each sample. In experiments where collected medium was subjected to SDS/PAGE, the results were analyzed against total protein concentrations in respective samples.

\section{Proliferation assay}

CellTiter assay A total of 10,000 cells/well were cultured in a 96-well plate for $24 \mathrm{~h}$. Next, complete medium was changed to serum-free medium (SFM) supplemented with $0.2 \%$ fatty acid-free BSA for another $24 \mathrm{~h}$, after which cells were treated with FTY720 as indicated. Proliferation was measured using the CellTiter 96 Aqueous One Solution cell proliferation assay kit, according to the manufacturer's instructions.

${ }^{3}$ H-thymidine incorporation assay For this assay, 75,000 cells were cultured for $24 \mathrm{~h}$ on $35 \mathrm{mM}$ as described previously. After being serum starved for $24 \mathrm{~h}$, the cells were treated as indicated. Four hours before ending the experiments, cells were incubated with ${ }^{3} \mathrm{H}$-thymidine $(0.4 \mu \mathrm{Ci} / \mathrm{mL})$. Then, the cells were washed 3 times with ice-cold PBS. After that, the cells were incubated with $5 \%$ trichloroacetic acid (TCA) for $10 \mathrm{~min}$ followed by incubation with $0.1 \mathrm{~N} \mathrm{NaOH}$ for another $10 \mathrm{~min}$. The radioactivity was measured by using a Wallac 1410 liquid scintillation counter (Wallac OY, Turku, Finland).

Fluorescence-activated cell sorting Cells were grown in $10 \mathrm{~cm}$ plates until $70 \%$ confluency was reached. Next, complete medium was changed to SFM overnight, and cells were treated with $1 \mu \mathrm{M}$ FTY720 for $24 \mathrm{~h}$. After being washed with ice-cold PBS and detached, 500,000 cells were suspended in PI solution $(0.05 \mathrm{mg} / \mathrm{mL}$ PI, $3.8 \mu \mathrm{M}$ sodium citrate, and $0.1 \%$ Triton-X-100 in PBS) and incubated for $15 \mathrm{~min}$ at room temperature. Finally, the samples were analyzed by flow cytometry using ModFit LT 4.1 software (Verity Software House, Inc., Topsham, ME, USA).

Published by Bioscientifica Ltd. 
A
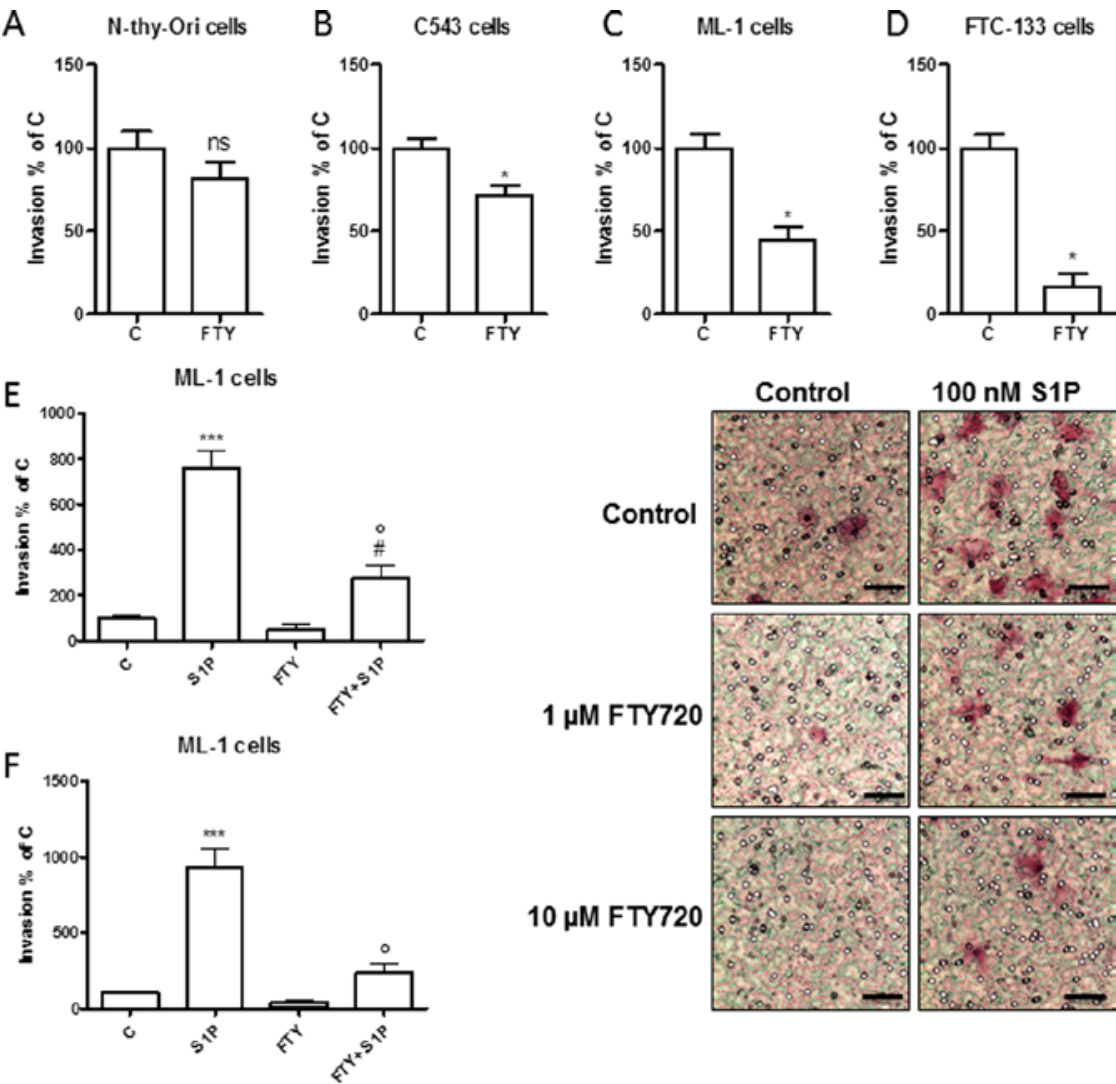

\section{Figure 1}

The effect of FTY720 on invasion of thyroid cancer cells. (A) Lack of an effect of $10 \mu \mathrm{M}$ FTY720 on invasion (17 h) of N-thy-Ori cells. (B-D) Invasion of anaplastic $\mathrm{C} 643$ cells ( $6 \mathrm{~h}$ ), follicular ML-1 cells (6h), and follicular FTC-133 (20h) thyroid cancer cells is blocked by $10 \mu \mathrm{M}$ FTY720. (E-F) FTY720 attenuates S1P-evoked invasion of ML-1 cells. Cells were preincubated for $1 \mathrm{~h}$ with $1 \mu \mathrm{M}$ FTY720 (E) or 10 $\mu \mathrm{M}$ FTY720 (F) and allowed to invade toward $100 \mathrm{nM} \mathrm{S1P}$ and $10 \%$ LS-FBS for 4-6h. The scale bar in the photos are $50 \mu \mathrm{m}$. (G) FTY720 $(10 \mu \mathrm{M}$ and $1 \mathrm{~h}$ preincubation) attenuates S1P-evoked invasion of FTC-133 cells $(20 \mathrm{~h})$. (H) Cells were preincubated for $1 \mathrm{~h}$ with $1 \mu \mathrm{M} \mathrm{p}-\mathrm{FTY720}$ and allowed to invade toward $100 \mathrm{nM}$ S1P and $10 \%$ LS-FBS for $4 \mathrm{~h}$. p-FTY720 was present in both the upper and lower chambers during the entire experiments. The results are the mean \pm S.E.M., $n \geq 3$. ${ }^{*} P<0.05, * * P<0.01$, and $* * * P<0.001$ indicate a statistically significant difference between FTY720 treatment and respective control. ${ }^{\circ}$ indicates a statistically significant difference between S1P treatment and FTY720+S1P. \#indicates a statistically significant difference between FTY720 treatment and FTY720+S1P.

Invasion assay Invasion experiments were performed on $6.5 \mathrm{~mm}$-diameter Trans-well chambers with $8 \mathrm{~m}$ pore size. The membranes were coated with $5 \mathrm{~g} / \mathrm{cm} 2$ collagen IV overnight and reconstituted with SFM for $1 \mathrm{~h}$ at $37^{\circ} \mathrm{C}$ prior to the experiment. After being serum starved overnight, cells were preincubated for $1 \mathrm{~h}$ with 1 or $10 \mu \mathrm{M}$ FTY720. A cell suspension containing 100,000 cells was added to the upper wells, and SFM with or without S1P and 10\% lipid-stripped FBS (LS-FBS) was added to the lower wells. In experiments with FTY720, FTY720 was present in both chambers during the entire experiment. The cells were allowed to migrate in the incubator as indicated. Next, unmigrated cells from the topside of the membrane were wiped off with a cotton swab. The migrated cells were fixed in $2 \%$ paraformaldehyde in PBS for 10 min and stained with $0.1 \%$ crystal violet in $20 \%$ methanol for $5 \mathrm{~min}$. The membranes were rinsed and allowed to dry. The cells were counted with 40x magnification in eight microscopic fields in a straight line bisecting the membrane.

Zymography Cells were stimulated as indicated, conditioned medium was collected, and cells were lysed as described previously. Next, equal volumes of sample medium were mixed with loading buffer $(0.1 \mathrm{M}$ Trisphosphate buffer ( $\mathrm{pH}$ 6.8) containing $20 \%$ glycerol, $6 \%$ SDS, $0.04 \%$ bromphenol blue). The samples were electrophoresed on 10\% SDS-polyacrylamide gels containing $1 \mathrm{mg} / \mathrm{mL}$ gelatin. Gels were then incubated 
A

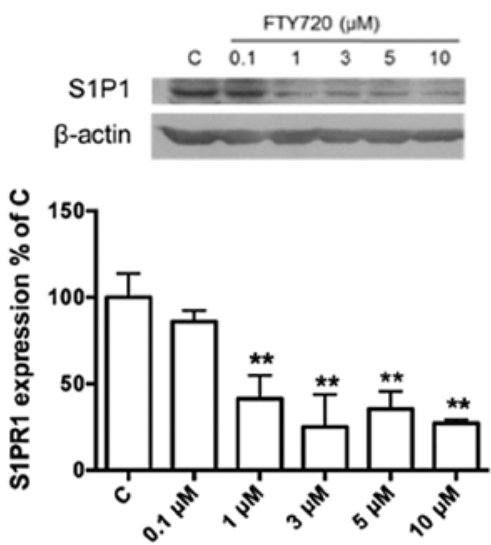

C
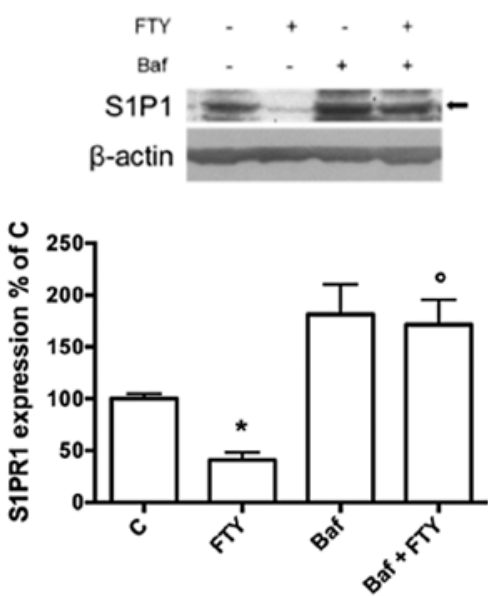

B

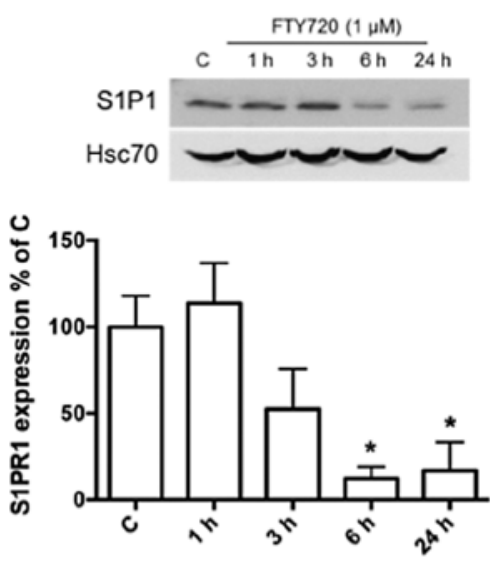

D
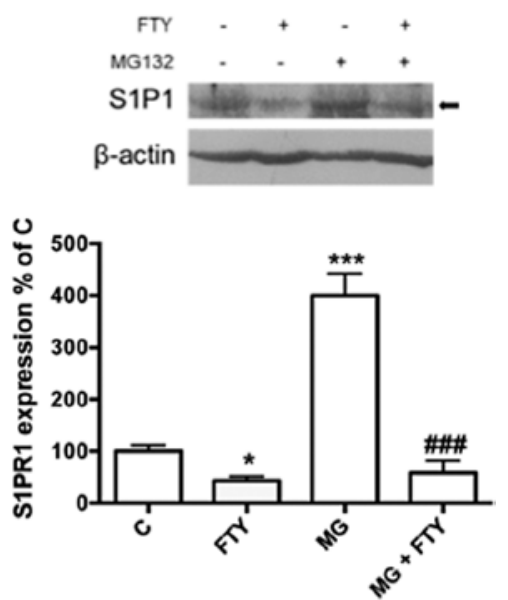

Figure 2

FTY720 causes lysosomal degradation of S1P (A-B) The expression of $\mathrm{S}_{1} \mathrm{P}_{1}$ is downregulated by FTY720 after $5 \mathrm{~h}$ in a concentration- (A) and time-dependent (B) manner. (C) The lysosomal inhibitor Bafilomycin (100 $\mathrm{nM}, 1 \mathrm{~h}$ preincubation) attenuates downregulation of S1 $\mathrm{P}_{1}$ evoked by $1 \mu \mathrm{M}$ FTY720. The cells were incubated with FTY720 for $24 \mathrm{~h}$. (D) Lack of an effect of the proteasome inhibitor MG132 $(10 \mu \mathrm{M}, 1 \mathrm{~h}$ preincubation) on the FTY720-evoked $(1 \mu \mathrm{M}$, $24 \mathrm{~h}$ ) downregulation of $\mathrm{S}_{1} \mathrm{P}_{1}$. The upper panel shows Western blot pictures and the lower panel shows densitometric analyses. The arrows in $\mathrm{C}$ and $\mathrm{D}$ indicate the $\mathrm{S}_{1} \mathrm{P}_{1}$ protein. The results are the mean \pm s. E.M., $n \geq 3 . * P<0.05, * * P<0.01$, and $* * * P<0.001$ indicate a statistically significant difference between FTY720 treatment and respective control. ${ }^{\circ}$ indicates a statistically significant difference between FTY720 treatment and FTY720 + inhibitor. \#indicates a statistically significant difference between inhibitor treatment and FTY720+inhibitor. in zymo buffer I $(50 \mathrm{mM}$ Tris- $\mathrm{HCl}$ containing $2.5 \%$ Tween 80 and $0.02 \mathrm{NaN}_{3}(\mathrm{pH} \mathrm{7.5))} \mathrm{for} 30 \mathrm{~min}$, followed by incubation for another $30 \mathrm{~min}$ in the zymo buffer II (zymo buffer I in which $1 \mu \mathrm{M} \mathrm{ZnCl}$ and $5 \mathrm{mM} \mathrm{CaCl}_{2}$ were added). Finally, to allow gelatinolytic activity, gels were incubated in zymo buffer III containing $50 \mathrm{mM}$ Tris- $\mathrm{HCl}, 5 \mathrm{mM} \mathrm{CaCl}, 1 \mu \mathrm{M} \mathrm{ZnCl}$, and $0.02 \% \mathrm{NaN}_{3}(\mathrm{pH}$ 7.5) overnight at $37^{\circ} \mathrm{C}$. To detect bands representing gelatinolytic activity, gels were stained with Coomassie Brilliant Blue R250 for 1-2 h and destained for 30-60 min. Gels were then packed in plastic bags and scanned. Clear bands showing gelatinolytic activity were quantified by Image software. MMP activity was normalized with the respective total protein concentrations in the plates.

\section{Chick embryo chorioallantoic membrane}

model The chorioallantoic membrane (CAM) model has been described elsewhere (Ossowski \& Reich 1980, Björk et al. 2015). In brief, fertilized chicken eggs were placed with sharp edge down in a humidified egg incubator $\left(37^{\circ} \mathrm{C}\right)$ and incubated for 3 days in the rocking mode. On egg development day (EDD) 4, 2-mm holes were made on the sharp edge of the eggs. The holes were covered with tape and the eggs were incubated stationary for 3 days, sharp edge up. On $\operatorname{EDD} 7$, the holes were enlarged to approximately $2 \mathrm{~cm}$ in diameter. On EDD 8, ML-1 cells were harvested, suspended in DMEM medium without supplements $\left(1 \times 10^{6}\right.$ cells per $10 \mu \mathrm{L}$ medium), and mixed 1:1 with ice-cold Matrigel. Then, $20 \mu \mathrm{L}$ of the cell suspension was pipetted onto the CAM within the perimeter of a silicone ring. The holes were sealed with sealing film, whereafter the eggs were placed back into the incubator. The ML-1 tumors were treated on EDD 9-11

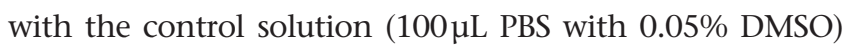
or with FTY720 $(100 \mu \mathrm{L}$ PBS with $1 \mu \mathrm{g}$ FTY720 and $0.05 \%$ DMSO), respectively. The eggs were photographed and the tumor areas from EDD 9 and EDD 12 were measured using Image software. Relative tumor areas were calculated by dividing the tumor area by the silicone ring area of each sample. The obtained values were used to calculate the percentage change in relative tumor area from EDD 9 to EDD 12. The normalized percentage change values were used for statistical analysis.

Published by Bioscientifica Ltd. 
A

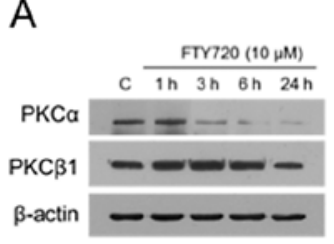

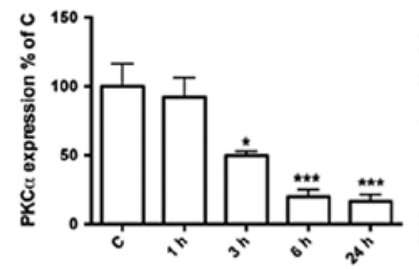

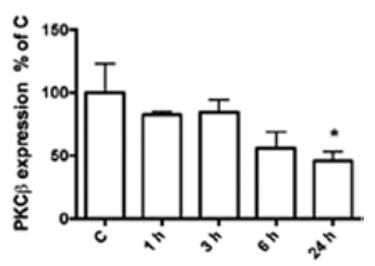

B

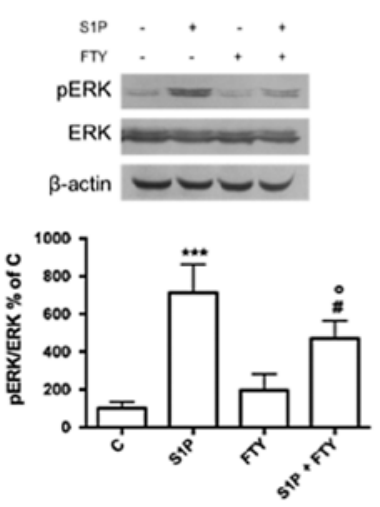

C
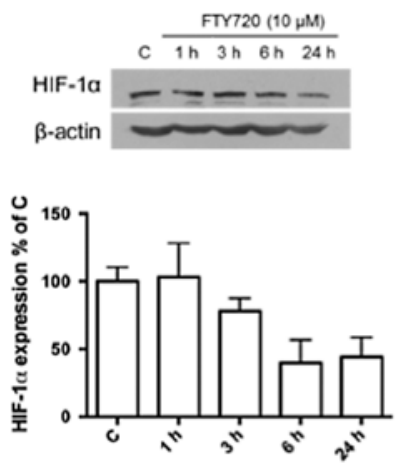

E

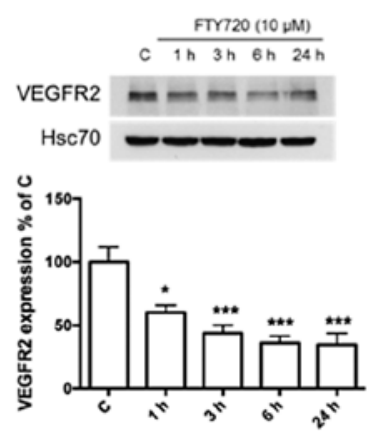

Figure 3

The effect of FTY720 on signaling intermediates in ML-1 cells. (A) $10 \mu \mathrm{M}$ FTY720 attenuates the expression of $\mathrm{PKC} \alpha$ in a time-dependent manner and PKC $\beta$ I expression after $24 \mathrm{~h}$. (B) FTY720 (1 h preincubation and $1 \mu \mathrm{M}$ ) attenuates phosphorylation of ERK1/2 evoked by S1P (100 $\mathrm{nM}$ and $30 \mathrm{~min}$ ). (C) Lack of a significant effect ofFTY720 $(10 \mu \mathrm{M})$ on HIF-1 $\alpha$ expression. (D-E) FTY720 inhibits the expression of VEGFR2 in a concentration- (FTY720, $5 \mathrm{~h}$, and $0.1-10 \mu \mathrm{M}$ ) and time- dependent (FTY720, 10 $\mu \mathrm{M}$ and 1-24h) fashion. The upper panel shows Western blot pictures and the lower panel shows densitometric analyses. The results are the mean \pm S.E.M., $n \geq 3$. $* P<0.05, * * P<0.01$, and $* * * P<0.001$ indicate a statistically significant difference between FTY720 treatment and respective control. 'Indicates a statistically significant difference between S1P treatment and FTY720+S1P. \#indicates a statistically significant difference between FTY720 treatment and FTY720+S1P.
Scratch-wound experiment FTC133 cells were seeded onto 96 -well plates at densities of $1 \times 10^{5}$ and $1.5 \times 10^{5}$ cells per well, respectively. The cells were grown for $24 \mathrm{~h}$, whereafter the wounds were created by employing a wound maker tool (WoundMaker, Essen Bioscience, Ann Arbor, MI, USA). Then, the cells were washed twice with medium without supplements. Thereafter, the medium wash changed to DMEM and Ham's F12 medium (1:1) supplemented with 5\% LS-FBS and $1 \%$ penicillin-streptomycin and mitomycin C $(1 \mu \mathrm{g} / \mathrm{mL})$ containing either the control solution (DMSO) or FTY720. The imaging was conducted with an automated live-cell imaging apparatus (Cell-IQ, CM Technologies, Tampere, Finland). The wound area analysis was conducted with the Cell-IQ Analyzer software.

\section{Statistics}

All numerical data are presented as the mean \pm s.E.M. for at least three independent measurements. Statistical analysis of two means was performed with Student's t-test. Three or more means were analyzed with one-way ANOVA and Bonferroni's post hoc test. A probability value of less than 0.05 was considered statistically significant.

\section{Results}

\section{The effect of FTY720 on invasion of thyroid cancer cells}

Our previous investigations had shown that S1P is a potent enhancer of ML-1 follicular thyroid cancer cell migration via $\mathrm{S}_{1} \mathrm{P}_{1,3}$, but not of normal thyroid cells (Balthasar et al. 2006, Bergelin et al. 2009, 2010). Furthermore, FTY720 has been shown to inhibit migration of both noncancerous (Matloubian et al. 2004, Lo et al. 2005, Mousseau et al. 2012) and cancerous cells (Tonelli et al. 2010, Lim et al. 2011). Thus, the aim of this study was to investigate the effect of FTY720 on invasion of thyroid cancer cells, and for this purpose, we tested several thyroid cell lines.

Published by Bioscientifica Ltd 
A

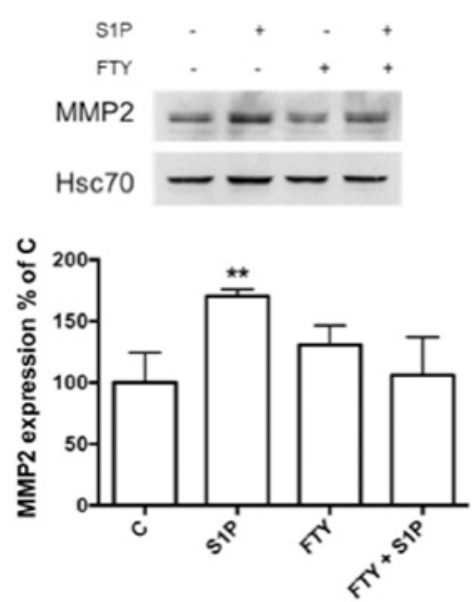

B
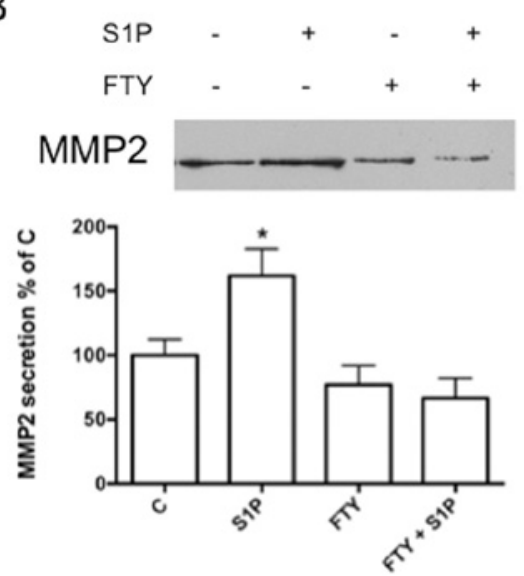

C
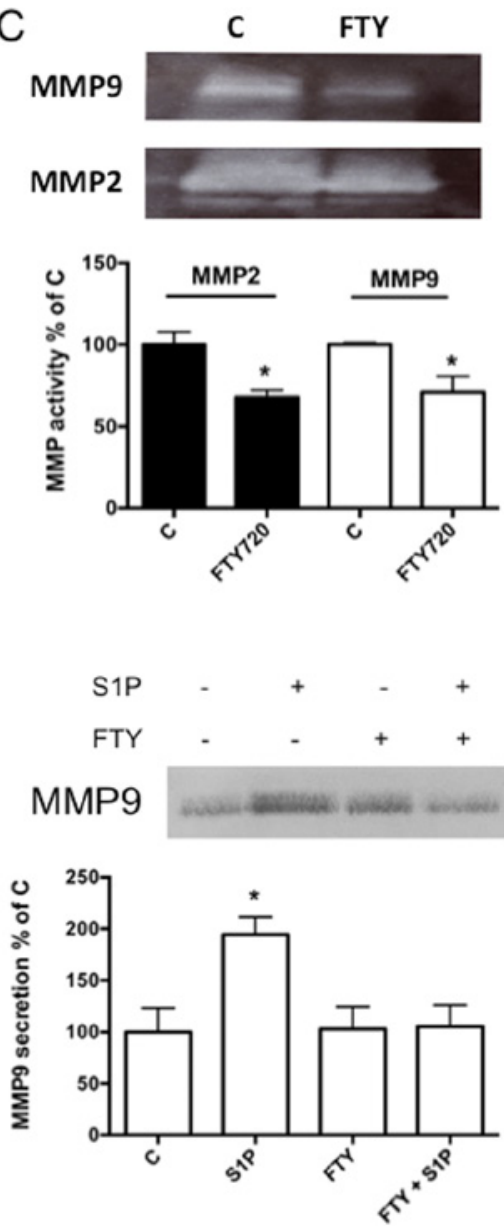

Figure 4

FTY720 attenuates MMP2 and MMP9 secretion. (A) Cells were stimulated with S1P (100 nM for $48 \mathrm{~h}$ ) in the presence or absence of $10 \mu \mathrm{M}$ FTY720 ( $1 \mathrm{~h}$ preincubation) and the expression of MMP2 was measured. (B) FTY720 $(10 \mu \mathrm{M}, 1 \mathrm{~h}$ preincubation) attenuates S1P-evoked $(100 \mathrm{nM}$, 4h) MMP2 and MMP9 secretion. In (A-B), FTY720 was present during the entire experiment. (C) Incubating the cells with $10 \mu \mathrm{M}$ FTY720 for $24 \mathrm{~h}$ decreased basal MMP2 and MMP9 activity. The upper panel shows Western blot or zymography pictures and the lower panel shows densitometric analyses. The amount of secreted MMPs was normalized against total protein concentrations in respective samples. The results are the mean \pm s.E.M., $n \geq 3 . * P<0.05$ and $* * P<0.01$ indicate a statistically significant difference between FTY720 or S1P treatment and respective control.
As can be seen in Fig. 1A, the invasion of normal thyroid cells was not affected by FTY720, but the basal invasion of all thyroid cancer cells tested was decreased after incubation with $10 \mu \mathrm{M}$ FTY720 (Fig. 1B-D). Moreover, invasion of both ML-1 cells (Fig. 1E and F) and FTC-133 cells (Fig. 1G) evoked by $100 \mathrm{nM}$ S1P was attenuated by FTY720. Next, we investigated if the phosphorylated form of FTY720 (p-FTY720) could show similar effects in ML-1 cells. Similar to FTY720, p-FTY720 ( $1 \mu \mathrm{M}$ and $1 \mathrm{~h}$ preincubation) was able to attenuate the S1P-evoked invasion of ML-1 cells (Fig. 1H). Taken together, FTY720 inhibits both basal and S1P-induced invasion of thyroid cancer cells.

\section{FTY720 causes lysosomal degradation of S1P}

Previous studies have shown that FTY720 has the ability to downregulate and degrade $\mathrm{S}_{1,3}$ in the proteasome (Oo et al. 2007, Mousseau et al. 2012). As FTY720 was able to inhibit invasion in our experiments, we thus tested whether FTY720 could affect the expression of $\mathrm{S}_{1} \mathrm{P}_{1,3}$ in
ML-1 cells. We treated the cells with FTY720 $(0.1,1,3$, 5 , and $10 \mu \mathrm{M})$ for different times (1, 3, 6, and $24 \mathrm{~h})$, and could show that FTY720 was able to downregulate $\mathrm{S}_{1} \mathrm{P}_{1}$ in a concentration- and time-dependent manner (Fig. 2A-B). However, to downregulate $\mathrm{S}_{1} \mathrm{P}_{3}$, the cells had to be incubated with $10 \mu \mathrm{M}$ FTY720 (the highest concentration tested) for $24 \mathrm{~h}$ (results not shown). Next, we asked if FTY720 caused degradation of $\mathrm{S}_{1} \mathrm{P}_{1}$; therefore, we tested the effect of the lysosome inhibitor Bafilomycin and the proteasome inhibitor MG132. Bafilomycin (100 nM, $1 \mathrm{~h}$ preincubation) was able to abolish the downregulation of $\mathrm{S}_{1} \mathrm{P}_{1}$ evoked by $1 \mu \mathrm{M}$ FTY720 (Fig. 2C). Interestingly, MG132 increased the expression of $\mathrm{S}_{1} \mathrm{P}_{1}$. However, MG132 was not able to abolish the response caused by $1 \mu \mathrm{M}$ FTY70 (Fig. 2D). To further confirm our results on the role of proteasome in degradation of $\mathrm{S}_{1} \mathrm{P}_{1}$ caused by FTY720, we performed ubiquitination studies. In these studies, we were not able to detect any ubiquitination of the receptor (results not shown). Collectively, FTY720 downregulates $\mathrm{S}_{1} \mathrm{P}_{1}$ by inducing lysosomal degradation. In contrast to its rapid effects at low concentrations on

Published by Bioscientifica Ltd 
A

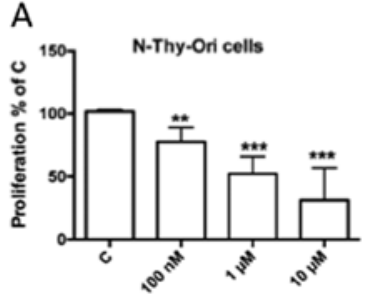

D

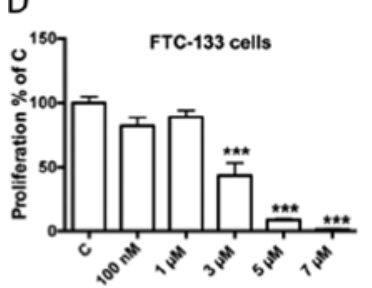

G

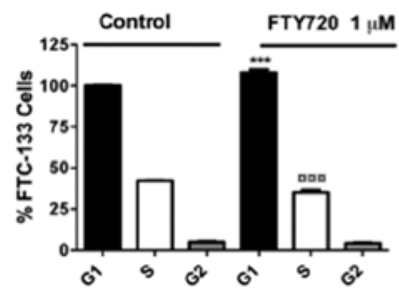

H Control
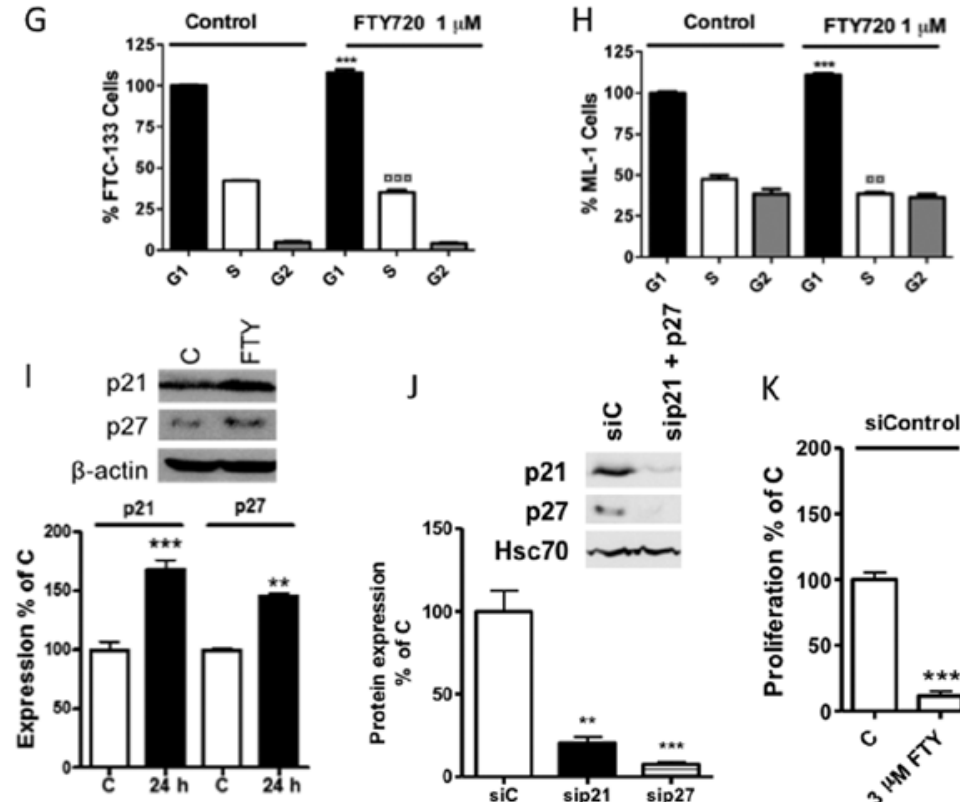

E
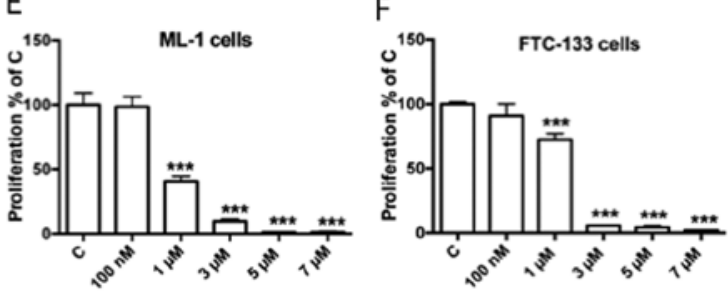

B

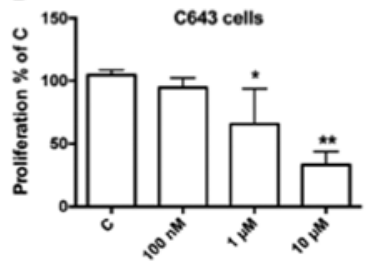

C

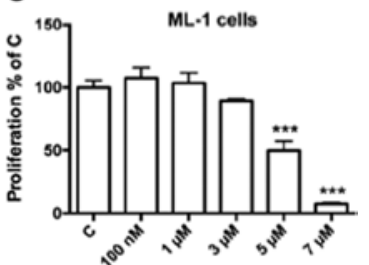

$F$
Figure 5

FTY720 inhibits thyroid cell proliferation. FTY720 attenuated in a concentration-dependent manner the proliferation of (A) N-Thy-Ori thyroid cells, (B) anaplastic C643 cancer cells, (C) follicular ML-1 cancer cells, and (D) follicular FTC-133 cancer cells using the CellTiter analysis methods. The cells were incubated with FTY720 for $24 \mathrm{~h}$. (E-F) FTY720 blocked proliferation of follicular ML-1 and FTC-133 cells investigated with the ${ }^{3} \mathrm{H}$-thymidine incorporation assay. (G-H) Incubating with $1 \mu \mathrm{M}$ FTY720 for $24 \mathrm{~h}$ accumulated ML-1 and FTC-133 cells in the G1 phase and decreased cells in the $S$ phase of the cell cycle. (I) Incubating ML-1 cells with $1 \mu \mathrm{M}$ FTY720 for $24 \mathrm{~h}$ upregulated the expression of p21 and p27. (J) ML-1 cells transfected with control siRNA or p21/p27 siRNA. The representative blots show the expression of p21 and p27 compared to the control. Hsc70 was used as loading control.

(K) Treatment with $\mathrm{p} 21+\mathrm{p} 27$ siRNA attenuates the effect of FTY720 on the proliferation of ML-1 cells. Proliferation was measured using the CellTiter proliferation assay kit. The results are the mean \pm s.E.M., $n \geq 3 .{ }^{*} P<0.05, * * P<0.01$, ${ }^{\infty} P<0.01$, oxo $P<0.001$, and $* * * P<0.001$ indicate a statistically significant difference between FTY720 treatment and respective control.
$\mathrm{S}_{1} \mathrm{P}_{1}$, FTY720 requires longer incubations and higher concentrations to be able to downregulate $\mathrm{S}_{1} \mathrm{P}_{3}$.

\section{The effects of FTY720 on signaling intermediates in ML-1 cells}

Previously, we showed that the S1P-induced migration of ML-1 cells is mediated by PKC isoforms, ERK1/2, SK1 (Balthasar et al. 2008, Bergelin et al. 2010), and HIF$1 \alpha$ (Kalhori et al. 2013). Moreover, a cross talk between $\mathrm{S}_{1} \mathrm{P}_{1}$ and VEGFR2 of crucial importance for migration exists in ML-1 cells. Hence, we investigated the effect of FTY720 $(0.1,1$, and $10 \mu \mathrm{M})$ for different times (1, 3,6 , and $24 \mathrm{~h}$ ) on these signaling intermediates. Our results showed that $1 \mu \mathrm{M}$ FTY720 had no effect on the expression of neither PKC $\alpha$ nor PKC $\beta$ I (results not shown). However, after incubating the cells with $10 \mu \mathrm{M}$ FTY720, the expression of PKC $\alpha$ was downregulated in a time-dependent manner, whereas the expression of PKC $\beta I$ was significantly downregulated after $24 \mathrm{~h}$ only (Fig. 3A). Interestingly, FTY720 was without an effect on both the total amount of ERK1/2 and the basal phosphorylation of ERK1/2 (results not shown). However, FTY720 attenuated the S1P-evoked phosphorylation of ERK1/2 (Fig. 3B). We also investigated the expression of HIF- $1 \alpha$ but were not able to show a statistically significant decrease of HIF-1 $\alpha$ expression after incubation with $10 \mu \mathrm{M}$ FTY720 (Fig. 3C). An important observation was that FTY720 decreased the expression of VEGFR2 in a time- and concentration-dependent fashion (Fig. 3D-E).

We have previously shown that SK1 is of importance in regulating ML-1 cell migration (Bergelin et al. 2009), 
A

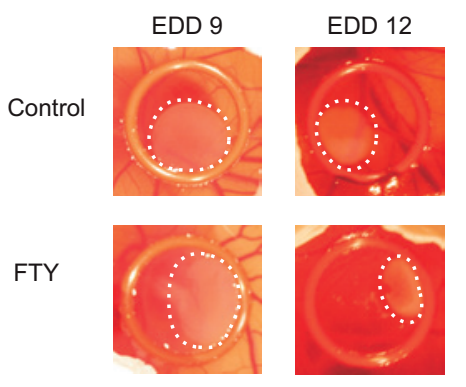

C

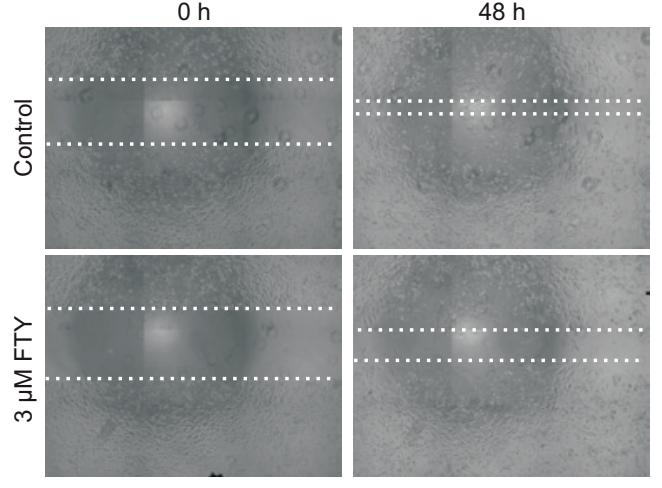

B

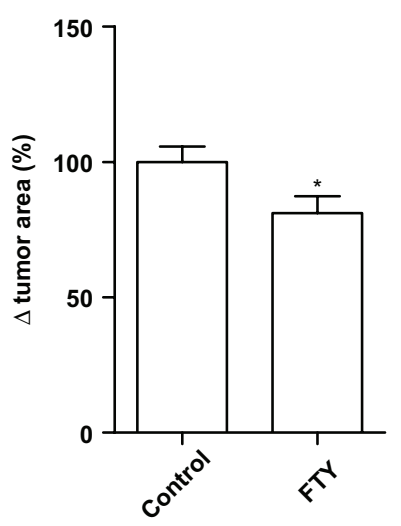

D

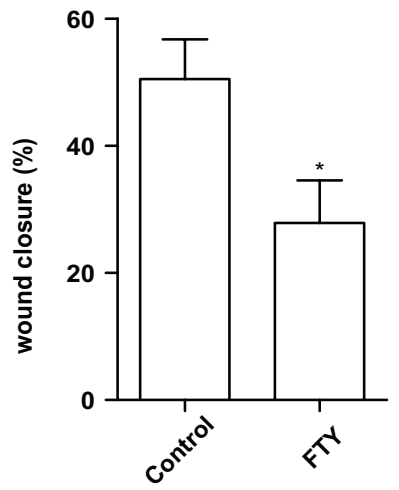

Figure 6

FTY720 inhibits the growth of ML-1 cells in a chick embryo CAM model and blocks the migration of FTC133 cells in a scratch-wound experiment. (A) Representative images of control and FTY720-treated ML-1 cell tumors in the CAM. (B) Quantification of the relative change in ML-1 cell tumor area. The results are mean \pm S.E.M., $n=13$ eggs (control), 14 eggs (FTY720 treated), ${ }^{*} P<0.05$. (C) Representative images of FTC133 cells in a scratch-wound experiment.

(D) Quantification of the wound closure at the 48-h time point. The results are mean \pm S.E.M., $n=4, * P<0.05$. and previously, Tonelli and coworkers showed that FTY720 downregulated SK1 (Tonelli et al. 2010). We were, however, not able to show any effects of FTY720 on the levels of SK1 in ML-1 cells (results not shown). Taken together, FTY720 inhibits signaling intermediates of crucial importance for ML-1 cell invasion.

\section{FTY720 modulates MMP2 and MMP9}

Previous studies have shown that FTY720 inhibits MMP2 and MMP9 in human glioblastoma cell lines (Zhang et al. 2014). In addition, we showed earlier that $S 1 P$ via $S 1 P_{1,3}$ induced the secretion of MMP2 and MMP9 in ML-1 cells, and that these MMPs are of importance for S1P-induced invasion (Kalhori \& Törnquist 2015). In accordance with previous results, FTY720 attenuated the S1P-evoked upregulation of MMP2 after $48 \mathrm{~h}$ (Fig. 4A), and the S1P-evoked secretion of both MMP2 and MMP9 (Fig. 4B). Interestingly, FTY720 per se did not decrease the secretion of MMP2 or MMP9 (Fig. 4B). However, an important observation was that when we exposed ML-1 cells to $10 \mu \mathrm{M}$ FTY720 for $24 \mathrm{~h}$, FTY720 decreased the activity of the secreted MMP2 and MMP9 (Fig. 4C). In conclusion, FTY720 attenuates S1P-evoked secretion of MMP2 and
MMP9 as well as MMP2 expression. In addition, FTY720 decreases MMP2 and MMP9 activity.

\section{FTY720 inhibits thyroid cancer cell proliferation}

As FTY720 decreased the invasion of the thyroid cancer cells, we investigated the effect of different concentrations of FTY720 on the proliferation of normal thyroid cells and several thyroid cancer cell lines. Results obtained using the CellTiter assay showed that FTY720 was able to attenuate proliferation of normal N-Thyr-Ori 3-1 and anaplastic C643 cells in a concentration-dependent manner (Fig. 5A-B). By performing both CellTiter and ${ }^{3} \mathrm{H}$-thymidine incorporation assays, we could show that FTY720 is able to inhibit proliferation of ML-1 and FTC-133 cells in a concentration-dependent fashion (Fig. 5C-D, CellTiter; Fig. 5E-F, ${ }^{3} \mathrm{H}$-thymidine incorporation). Next, by performing FACS analysis, we found that FTY720 inhibited proliferation of ML-1 and FTC-133 cells by accumulating cells in the G1 phase and decreasing the amount of cells in the $S$ phase of the cell cycle (Fig. 5G-H). Next, we investigated the expression of proteins involved in cell cycle regulation and found that incubating the cells with $1 \mu \mathrm{M}$ FTY720 for $24 \mathrm{~h}$ induced

Published by Bioscientifica Ltd. 
an upregulation of p21 and p27 in ML-1 cells (Fig. 5I). To investigate the significance of $\mathrm{p} 21$ and $\mathrm{p} 27$ in proliferation, ML-1 cells were transfected with siRNA against p21 and p27. The results showed that the basal proliferation was significantly enhanced and the $3 \mu \mathrm{M}$ FTY720-induced inhibition of proliferation was attenuated (Fig. 5J-K).

To increase the efficiency of therapeutic drugs, combined therapy is becoming an attractive tool in the treatment of different diseases. Therefore, we tested both FTY720 and p-FTY720 $(1 \mu \mathrm{M})$ in combination with doxorubicin $(0.1,0.5,1$, and $5 \mu \mathrm{M})$ to investigate whether an additive or synergistic inhibitory effect on proliferation could be obtained. However, we were not able to see any additive or synergetic effects of these compounds (results not shown). Taken together, FTY720 inhibits proliferation of thyroid cancer cell lines. In ML-1 cells, this inhibition is due to an increase in p21 and p27, and an arrest in the G1 phase of the cell cycle.

\section{FTY720 inhibits thyroid cancer cell growth in the chick CAM model and cell migration in the scratch-wound assay}

To assess the antiproliferative effect of FTY720 in vivo, we employed the chick CAM model (Ribatti 2014). ML-1 cells were implanted in to the CAM and allowed to develop into a tumor. The growth of these tumors was slightly but significantly attenuated by FTY720 treatment (Fig. 6A-B). The effect of FTY720 on FTC133 cell migration in a scratch-wound model was investigated, and the results showed a significant attenuation in wound healing upon $3 \mu \mathrm{M}$ FTY720 treatment (Fig. 6C-D).

\section{Discussion}

Currently, not many studies address the importance of sphingolipid signaling in thyroid cancer progression, although we have shown that S1P and SK1 are important players in regulating many essential cellular events in different types of thyroid cancer cells (Balthasar et al. 2006, Bergelin et al. 2009, 2010, Kalhori et al. 2013, Törnquist 2013, Kalhori \& Törnquist 2015). In addition, our in vitro results have been corroborated by investigations on human thyroid samples (Guan et al. 2011). In this study, we have investigated a novel approach to curtail the proliferation and invasion of thyroid cancer cells. We evaluated the effect of FTY720, a drug that is approved by both the FDA and the EMA to be clinically used for treatment of MS on thyroid cancer cell proliferation and invasion.
Our results showed that FTY720 did not affect the invasion of normal thyroid cells; however, the basal invasion of all thyroid cancer cell lines tested and the S1P-evoked invasion of ML-1 and FTC-133 cells were attenuated by FTY720. Furthermore, p-FTY720 was able to block the S1P-induced invasion of ML-1 cells. FTY720 also potently attenuated migration of FTC-133 cells in a scratch-wound assay. Our results are in line with previously published data, showing that FTY720 is able to inhibit migration of noncancerous cells (Mousseau et al. 2012) as well as several cancer cell types, including breast cancer cells (Tonelli et al. 2010, Lim et al. 2011), liver cancer cells (Li et al. 2012), and prostate cancer cells (Tonelli et al. 2010). Thus, we suggest that FTY720 acts as an anti-invasive drug in thyroid cancer cells.

Results published earlier by Mousseau and coworkers showed that FTY720, at low concentrations (100 nM), caused both internalization and downregulation of $\mathrm{S}_{1} \mathrm{PR}_{1,3}$ in vascular smooth muscle cells (Mousseau et al. 2012). Our study showed that FTY720 clearly downregulated $\mathrm{S}_{1} \mathrm{P}_{1}$ in a concentration- and timedependent manner. Surprisingly, low concentration of FTY720 could not downregulate $\mathrm{S}_{1} \mathrm{P}_{3}$ in ML-1 cells. However, we were able to see decreased expression of $\mathrm{S}_{1} \mathrm{P}_{3}$ after incubating the cells with $10 \mu \mathrm{M}$ FTY720 for $24 \mathrm{~h}$.

Oo and coworkers showed that FTY720 caused proteasomal degradation of $\mathrm{S}_{1} \mathrm{PR}_{1,3}$ (Oo et al. 2007). However, our findings suggested that FTY720 induced degradation of $\mathrm{S}_{1} \mathrm{P}_{1}$ in the lysosome, but the normal maintenance of $\mathrm{S}_{1} \mathrm{P}_{1}$ in ML-1 cells occurs through proteasomal degradation. The observation that FTY720 is not able to degrade $\mathrm{S}_{1} \mathrm{P}_{1}$ in the proteasome was strengthened by the fact that we could no detect any ubiquitination of $\mathrm{S}_{1} \mathrm{P}_{1}$ in our investigations. Thus, based on our results, we conclude that FTY720 is a potent inhibitor of $\mathrm{S}_{1} \mathrm{P}_{1}$ and that it causes lysosomal degradation of the receptor. High concentrations of FTY720 are required to downregulate $\mathrm{S}_{1} \mathrm{P}_{3}$, highlighting the importance of cell specificity, and concentrations used in different studies.

S1P induces migration and invasion of ML-1 cells through several mediators, such as ERK1/2, PKC $\alpha$ and PKC $\beta I$, and HIF-1 $\alpha$. Furthermore, S1P communicates with VEGFR2, which is essential for migration (Balthasar et al. 2006, Bergelin et al. 2009, Kalhori et al. 2013, Kalhori \& Törnquist 2015). In this study, we were able to show that FTY720 downregulated both PKC $\alpha$ and PKC $\beta I$, but we were not able to see a statistically significant decrease in HIF-1 $\alpha$ expression. Moreover, FTY720 was also able to attenuate S1P-evoked phosphorylation of ERK1/2. Similarly, Zhang and coworkers could show that FTY720

Published by Bioscientifica Ltd 
inhibited ERK1/2 in human glioblastoma cell lines (Zhang et al. 2014). Interestingly, Tonelli and coworkers showed that FTY720, albeit at lower concentrations, was able to downregulate SK1 expression (Tonelli et al. 2010). We were, however, not able to see this in our study. Furthermore, FTY720 inhibited the expression of VEGFR2 in a time- and concentration-dependent fashion.

We have previously shown that S1P enhances MMP2/9 secretion and the expression of intracellular MMP2 in ML-1 cells (Kalhori \& Törnquist 2015). In this investigation, we show that these effects of S1P can be attenuated by FTY720. Furthermore, although FTY720 per se did not attenuate the secretion of MMP2/9, the activity of MMP2/9 in collected media was attenuated by FTY720. Our results are in line with the results of Zhang and coworkers, who demonstrated that FTY720 inhibited MMP2 and MMP9 expression and activity in human glioblastoma cell lines (Zhang et al. 2014). Taken together, FTY720 is able to downregulate signaling intermediates of importance for ML-1 cell invasion and migration.

FTY720 has been proven to inhibit proliferation of both normal and cancerous cells (Mousseau et al. 2012, Permpongkosol et al. 2002). In our study, FTY720 was able to block proliferation significantly in a concentrationdependent fashion with two methods tested. Of these, the ${ }^{3} \mathrm{H}$-thymidine incorporation assay proved to be a more sensitive method. Furthermore, using the CAM model, we could show that FTY720 slightly, but significantly, attenuated ML-1 tumor growth in ovo. In a previous report, Permpongkosol and coworkers showed that FTY720 inhibited proliferation of human prostate carcinoma DU145 cells by inducing apoptosis and arresting cells in the G1 phase of the cell cycle (Permpongkosol et al. (2002). In our study, we could also see an accumulation of both ML-1 cells and FTC-133 cells in the G1 phase. Furthermore, we observed an upregulation of p21 and p27, two important regulators of the G1 phase. Nevertheless, we were not able to strengthen the effect of FTY720 on proliferation by cotreatment with doxorubicin.

In conclusion, we suggest that FTY720, which is currently in clinical use for the treatment of MS, is an inhibitor of thyroid cancer cell proliferation and invasion. Perri and coworkers and Manfredi and coworkers described in recent reviews, and Dicitore and coworkers in a recent report, that there are, in fact, several small-molecule inhibitors targeted to thyroid cancer, albeit they have mostly been proven to have small over all effects (Perri et al. 2014, Manfredi et al. 2015, Dicitore et al. 2016). Thus, novel approaches to curtail and stop the progression of aggressive thyroid cancers to a metastatic and terminally fatal disease are urgently warranted. Therefore, we suggest that FTY720 could be beneficial in the treatment of thyroid cancer.

\section{Declaration of statement}

The authors declare that there is no conflict of interest that could be perceived as prejudicing the impartiality of the research reported.

\section{Funding}

The study was supported in part by the Sigrid Juselius Foundation, the Liv och Hälsa Foundation, The Academy of Finland, the Magnus Ehrnrooth foundation, the Swedish cultural foundation, the Minerva Foundation for Medical Research (all in Helsinki, Finland), and the Centre of Excellence in Cell Stress and Molecular Ageing (Åbo Akademi University), the Doctoral Network in Molecular Biosciences (Åbo Akademi University), and the Receptor Research Program (Åbo Akademi University and the University of Turku), all in Turku (Finland), which are gratefully acknowledged.

\section{Acknowledgments}

The authors thank Drs Johann Schönberger, Nils-Erik Heldin, and John Copeland for generously providing cell lines, and Erik Niemelä and Dr John Eriksson for invaluable advice on the use of the CAM model.

\section{References}

Alshaker H, Sauer L, Monteil D, Ottaviani S, Srivats S, Bohler T \& Pchejetski D 2013 Therapeutic potential of targeting SK1 in human cancers. Advances in Cancer Research 117 143-200. (doi:10.1016/ B978-0-12-394274-6.00006-6)

Alvarez SE, Milstien S \& Spiegel S 2007 Autocrine and paracrine roles of sphingosine-1-phosphate. Trends in Endocrinology and Metabolism 18 300-307. (doi:10.1016/j.tem.2007.07.005)

Balthasar S, Bergelin N, Lof C, Vainio M, Andersson S \& Tornquist K 2008 Interactions between sphingosine-1-phosphate and vascular endothelial growth factor signalling in ML-1 follicular thyroid carcinoma cells. Endocrine-Related Cancer 15 521-534. (doi:10.1677/ERC-07-0253)

Balthasar S, Samulin J, Ahlgren H, Bergelin N, Lundqvist M, Toescu EC, Eggo MC \& Tornquist K 2006 Sphingosine 1-phosphate receptor expression profile and regulation of migration in human thyroid cancer cells. Biochemical Journal 398 547-556. (doi:10.1042/BJ20060299)

Bergelin N, Blom T, Heikkila J, Lof C, Alam C, Balthasar S, Slotte JP, Hinkkanen A \& Tornquist K 2009 Sphingosine kinase as an oncogene: autocrine sphingosine 1-phosphate modulates ML-1 thyroid carcinoma cell migration by a mechanism dependent on protein kinase C-alpha and ERK1/2. Endocrinology 150 2055-2063. (doi:10.1210/en.2008-0625)

Bergelin N, Lof C, Balthasar S, Kalhori V \& Tornquist K 2010 S1P1 and VEGFR-2 form a signaling complex with extracellularly regulated kinase $1 / 2$ and protein kinase C-alpha regulating ML-1 thyroid carcinoma cell migration. Endocrinology 151 2994-3005. (doi:10.1210/en.2009-1387)

Björk JK, Åkerfelt M, Joutsen J, Puustinen MC, Cheng F, Sistonen L \& Nees M 2016 Heat-shock factor 2 is a suppressor of prostate cancer invasion. Oncogene 35 1770-1784. (doi:10.1038/onc.2015.241)

Dicitore A, Grassi ES, Caraglia M, Borgh MO, Gaudenzi G, Hofland LJ, Persani L \& Vitale G 2016 The cAMP analogs have potent antiproliferative effects on medullary thyroid cancer cell lines. Endocrine 51 101-112. (doi:10.1007/s12020-015-0597-7) 
Guan H, Liu L, Cai J, Liu J, Ye C, Li M \& Li Y 2011 Sphingosine kinase 1 is overexpressed and promotes proliferation in human thyroid cancer. Molecular Endocrinology 25 1858-1866. (doi:10.1210/me.2011-1048)

Haugen BR \& Sherman SI 2013 Evolving approaches to patients with advanced differentiated thyroid cancer. Endocrine Reviews 34 439-455. (doi:10.1210/er.2012-1038)

Kalhori V, Kemppainen K, Asghar MY, Bergelin N, Jaakkola P \& Tornquist K 2013 Sphingosine-1-phosphate as a regulator of hypoxia-induced factor-1alpha in thyroid follicular carcinoma cells. PloS One 8 e66189. (doi:10.1371/journal.pone.0066189)

Kalhori V \& Törnquist K 2015 MMP2 and MMP9 participate in S1Pinduced invasion of follicular ML-1 thyroid cancer cells. Molecular and Cellular Endocrinology 404 113-122. (doi:10.1016/j.mce.2015.01.037)

Kim DS, Franklyn JA, Boelaert K, Eggo MC, Watkinson JC \& McCabe CJ 2006 Pituitary tumor transforming gene (PTTG) stimulates thyroid cell proliferation via a vascular endothelial growth factor/kinase insert domain receptor/inhibitor of DNA binding-3 autocrine pathway. Journal of Clinical Endocrinology and Metabolism 914603 4611. (doi:10.1210/jc.2006-1291)

Kunkel GT, Maceyka M, Milstien S \& Spiegel S 2013 Targeting the sphingosine-1-phosphate axis in cancer, inflammation and beyond Nature Reviews. Drug Discovery 12 688-702. (doi:10.1038/nrd4099)

Li CX, Shao Y, Ng KT, Liu XB, Ling CC, Ma YY, Geng W, Fan ST, Lo CM \& Man K 2012 FTY720 suppresses liver tumor metastasis by reducing the population of circulating endothelial progenitor cells. PloS One $\mathbf{7}$ e32380. (doi:10.1371/journal.pone.0032380)

Lim KG, Tonelli F, Li Z, Lu X, Bittman R, Pyne S \& Pyne NJ 2011 FTY720 analogues as sphingosine kinase 1 inhibitors: enzyme inhibition kinetics, allosterism, proteasomal degradation, and actin rearrangement in MCF-7 breast cancer cells. Journal of Biological Chemistry 286 18633-18640. (doi:10.1074/jbc.M111.220756)

Lo CG, Xu Y, Proia RL \& Cyster JG 2005 Cyclical modulation of sphingosine-1-phosphate receptor 1 surface expression during lymphocyte recirculation and relationship to lymphoid organ transit. Journal of Experimental Medicine 201 291-301. (doi:10.1084/jem.20041509)

Manfredi GI, Dicitore A, Gaudenzi G, Caraglia M, Persani L \& Vitale G 2015 PI3K/Akt/mTOR signaling in medullary thyroid cancer: a promising molecular target for cancer therapy. Endocrine 48 363-370. (doi:10.1007/s12020-014-0380-1)

Matloubian M, Lo CG, Cinamon G, Lesneski MJ, Xu Y, Brinkmann V, Allende ML, Proia RL \& Cyster JG 2004 Lymphocyte egress from thymus and peripheral lymphoid organs is dependent on S1P receptor 1. Nature 427 355-360. (doi:10.1038/nature02284)

Mousseau Y, Mollard S, Richard L, Nizou A, Faucher-Durand K, Cook-Moreau J, Qiu H, Baaj Y, Funalot B, Fourcade L, et al. 2012 Fingolimod inhibits PDGF-B-induced migration of vascular smooth muscle cell by down-regulating the S1PR1/S1PR3 pathway. Biochimie 94 2523-2531. (doi:10.1016/j.biochi.2012.07.002)

Oo ML, Thangada S, Wu MT, Liu CH, Macdonald TL, Lynch KR, Lin CY \& Hla T 2007 Immunosuppressive and anti-angiogenic sphingosine 1-phosphate receptor-1 agonists induce ubiquitinylation and proteasomal degradation of the receptor. Journal of Biological Chemistry 282 9082-9089. (doi:10.1074/jbc.M610318200)

Ossowski L \& Reich E Experimental model for quantitative study of metastasis 1980 Cancer Research 40 2300-2309.

Paugh SW, Payne SG, Barbour SE, Milstien S \& Spiegel S 2003 The immunosuppressant FTY720 is phosphorylated by sphingosine kinase type 2. FEBS Letters 554 189-193. (doi:10.1016/S0014-5793(03)01168-2)

Permpongkosol S, Wang JD, Takahara S, Matsumiya K, Nonomura N, Nishimura K, Tsujimura A, Kongkanand A \& Okuyama A
2002 Anticarcinogenic effect of FTY720 in human prostate carcinoma DU145 cells: modulation of mitogenic signaling, FAK, cell-cycle entry and apoptosis. International Journal of Cancer 98 167-172. (doi:10.1002/ijc.10178)

Perri F, Pezzullo L, Chiofalo MG, Lastoria S, Di Gennaro F, Scarpati GD \& Caponigro F 2014 Targeted therapy: a new hope for thyroid carcinomas. Critical Reviews in Oncology/ Hematology 94 55-63. (doi:10.1016/j.critrevonc.2014.10.012)

Pyne S \& Pyne NJ 2013 New perspectives on the role of sphingosine 1-phosphate in cancer. Handbook of Experimental Pharmacology 216 55-71. (doi:10.1007/978-3-7091-1511-4_3)

Ribatti D 2014 The chick embryo chorioallantoic membrane as a model for tumor biology. Experimental Cell Research 328 314-324. (doi:10.1016/j.yexcr.2014.06.010)

Schonberger J, Bauer J, Spruss T, Weber G, Chahoud I, Eilles C \& Grimm D 2000 Establishment and characterization of the follicular thyroid carcinoma cell line ML-1. Journal of Molecular Medicine 78 102-110. (doi:10.1007/s001090000085)

Schweppe RE, Klopper JP, Korch C, Pugazhenthi U, Benezra M, Knauf JA, Fagin JA, Marlow LA, Copland JA, Smallridge RC, et al. 2008 Deoxyribonucleic acid profiling analysis of 40 human thyroid cancer cell lines reveals cross-contamination resulting in cell line redundancy and misidentification. Journal of Clinical Endocrinology and Metabolism 93 4331-4341. (doi:10.1210/jc.2008-1102)

Selvam SP \& Ogretmen B 2013 Sphingosine kinase/sphingosine 1-phosphate signaling in cancer therapeutics and drug resistance. Handbook of Experimental Pharmacology 216 3-27. (doi:10.1007/ 978-3-7091-1511-4_1)

Sobel K, Monnier L, Menyhart K, Bolinger M, Studer R, Nayler O, Gatfield J 2015 FTY720 Phosphate activates sphingosine-1-phosphate receptor 2 and selectively couples to Ga12/13/Rho/ROCK to induce myofibroblast contraction. Molecular Pharmacology 87 916-927. (doi:10.1124/mol.114.097261)

Strub GM, Maceyka M, Hait NC, Milstien S \& Spiegel S 2010 Extracellular and intracellular actions of sphingosine-1-phosphate. Advances in Experimental Medicine and Biology 688 141-155. (doi:10.1007/978-1-4419-6741-1_10)

Takabe K \& Spiegel S 2014 Export of sphingosine-1-phosphate and cancer progression. Journal of Lipid Research 55 1839-1846. (doi:10.1194/jlr.R046656)

Tonelli F, Lim KG, Loveridge C, Long J, Pitson SM, Tigyi G, Bittman R, Pyne S \& Pyne NJ 2010 FTY720 and (S)-FTY720 vinylphosphonate inhibit sphingosine kinase 1 and promote its proteasomal degradation in human pulmonary artery smooth muscle, breast cancer and androgen-independent prostate cancer cells. Cellular Signalling 22 1536-1542. (doi:10.1016/j.cellsig.2010.05.022)

Tornquist K 2013 Sphingosine 1-phosphate and cancer: lessons from thyroid cancer cells. Biomolecules 3 303-315. (doi:10.3390/ biom3020303)

Turner HE, Harris AL, Melmed S \& Wass JA 2003 Angiogenesis in endocrine tumors. Endocrine Reviews 24 600-632. (doi:10.1210/ er.2002-0008)

Vieira JM, Santos SC, Espadinha C, Correia I, Vag T, Casalou C, Cavaco BM, Catarino AL, Dias S \& Leite V 2005 Expression of vascular endothelial growth factor (VEGF) and its receptors in thyroid carcinomas of follicular origin: a potential autocrine loop. European Journal of Endocrinology 153 701-709. (doi:10.1530/ eje.1.02009)

Zhang L, Wang H, Zhu J, Ding K \& Xu J 2014 FTY720 reduces migration and invasion of human glioblastoma cell lines via inhibiting the PI3K/AKT/mTOR/p70S6K signaling pathway. Tumour Biology 35 10707-10714. (doi:10.1007/s13277-014-2386-y)

Received in final form 1 March 2016

Accepted 2 March 2016

Accepted Preprint published online 2 March 2016 http://erc.endocrinology-journals.org

DOI: 10.1530/ERC-16-0050
(C) 2016 Society for Endocrinology Printed in Great Britain 